\title{
Antiviral activities of Radix Isatidis polysaccharide against type II herpes simplex virus in vitro
}

\author{
Chunmei WANG ${ }^{1}$, Shiman RUAN², Xunmei GU ${ }^{1}$, Bin $\mathrm{ZHU}^{3 *}$
}

\begin{abstract}
This study investigated the antiviral activities of Radix Isatidis polysaccharide (RIP) against type II herpes simplex virus (HSV-2) in vitro. RIP was prepared from the Radix Isatidis root. The toxicity of RIP on Vero cells was detected. The direct killing effect of RIP on HSV-2, inhibitory effect of RIP on HSV-2 replication and inhibitory effect of RIP on HSV-2 adsorption were determined. Results showed that, RIP in concentration range of $25-800 \mathrm{mg} / \mathrm{L}$ had no toxic effect on Vero cells. RIP with different concentrations could not directly inactivate the HSV-2. The effective rates on inhibition of HSV-2 replication and adsorption in $800 \mathrm{mg} / \mathrm{L}$ RIP group were $71.57 \%$ and $48.37 \%$, respectively, which were the highest among different groups. In conclusion, RIP has the antiviral effect against HSV-2 in vitro. This effect mainly occurs in inhibiting the virus duplication and adsorption.
\end{abstract}

Keywords: Radix Isatidis; polysaccharide; HSV-2.

Practical Application: Radix Isatidis polysaccharide may be applied to treating type II herpes simplex virus related diseases.

\section{Introduction}

Type II herpes simplex virus (HSV-2) is a virus which majorly causes the genital herpes. HSV-2 infection is one of the major problems that affect the health of adults, especially in patients with immune impairment (Schiffer \& Corey, 2013). At present, the antiviral drug acyclovir is often clinically used to treat the HSV-2 infection. This drug exerts the antiviral action mainly by interfering with viral DNA replication. However, as the virus is easy to produce variation, the drug resistance still exists, so the treat outcome is not very satisfactory (Bacon et al., 2003). Therefore, it is urgent to develop a new mode of anti-HSV-2 drugs. In recent years, drug researchers have paid more and more attention to screening antiviral drugs from natural products. Isatidis Radix is a traditional herb in China. It is firstly collected in Shennong's Classic of Materia Medica. In traditional Chinese medicine (TCM), Isatidis Radix is bitter and cold, and has the efficacy of clearing away heat and toxicity and relieving sore throat. It is clinically used in treating viral and bacterial infection diseases (Ke et al., 2012). Polysaccharide is the main chemical component of Radix Isatidis. It is often obtained by water extraction from the root of Radix Isatidis. Many studies have shown that, Radix Isatidis polysaccharide (RIP) has the antioxidant and anti-inflammatory activities (Du et al., 2013), and can resist the viruses and enhance the body immunity (Zhao et al., 2008; Fang et al., 2009). Until now, the effect of RIP on HSV-2 is less reported. If it is confirm that RIP has antiviral activities against HSV-2, this will further broaden the range of therapeutic medicine for HSV-2 related diseases and the application range of RIP. In this study, it was the first time to investigate the antiviral activities of RIP against HSV-2. The objective of this study was to provide a basis for further studying the in vivo anti-HSV-2 activity of RIP and broadening the application scope of RIP.

\section{Materials and methods}

\subsection{Preparation of RIP}

Radix Isatidis root $(500 \mathrm{~g}$ ) was decocted (micro boiling) with $3000 \mathrm{~mL}$ distilled water for $4 \mathrm{~h}$. After heat filtering, the filter residue was decocted with $2000 \mathrm{~mL}$ of distilled water for $2 \mathrm{~h}$. The filtrates of two decoctions were merged, and were concentrated to volume of $200 \mathrm{~mL} .800 \mathrm{~mL}$ anhydrous ethanol was added, and the final alcohol concentration was adjusted to $80 \%$. After standing overnight, the supernatant was discarded, and the precipitate was dissolved in $100 \mathrm{~mL}$ of distilled water, and $400 \mathrm{~mL}$ anhydrous ethanol was added. The final alcohol concentration was adjusted to $80 \%$. After standing overnight, the supernatant was discarded, and the precipitate was collected. After freeze-drying, and the crude polysaccharide product was obtained. After deproteinization using Sevage method (Yanhua et al., 2014), the refined RIP was obtained. The sulfuric acid-phenol method showed the content of polysaccharide was $80 \%$.

\subsection{Cell culture}

Vero cells were cultured with Dulbecco's Modified Eagle's medium (DMEM) containing $\mathrm{mL} / \mathrm{L}$ fetal bovine serum (FBS), $100 \mathrm{U} / \mathrm{mL}$ penicillin and $100 \mu \mathrm{g} / \mathrm{mL}$ streptomycin at condition of $37^{\circ} \mathrm{C}$ and $5 \% \mathrm{CO}_{2}$. All the cell culture reagents were provided by Sigma-Aldrich Corp., MO (USA). 


\subsection{Determination of virus virulence}

HSV-2 (333 strains) was provided by Institute of Virology, Wuhan University (Wuhan, China). HSV-2 stock solution was diluted into 8 dilutions $\left(10^{-1}, 10^{-2}, 10^{-3}, 10^{-4}, 10^{-5}, 10^{-6}, 10^{-7}, 10^{-8}\right)$ using cell maintenance medium containing $2 \%$ FBS. The virus fluid with each dilution was inoculated to the 96-well culture plate of monolayer Vero cells, 4 repeated wells for each dilution, followed by culture at $37{ }^{\circ} \mathrm{C}$ with $5 \% \mathrm{CO}_{2}$. The normal Vero cells were set as control. The cytopathy was observed under the inverted microscope. Two fields of vision were selected from each well using the eyepiece micrometer, and 100 squares of each field of vision were selected to calculate the percentage of normal and abnormal cells. The 50\% tissue culture infection dose $\left(\mathrm{TCID}_{50}\right.$ ) was determined using the Reed-Muench method (Gustafsson et al., 2012).

\subsection{Determination of toxicity of RIP on Vero cells}

Vero cells were digested with trypsin, and the cell suspension $\left(1 \times 10^{6} \mathrm{cell} / \mathrm{mL}\right)$ was prepared. The cell suspension was seeded into 96 -well culture plates, $200 \mu \mathrm{L}$ in each well. After culture for $24 \mathrm{~h}$, RIP was added to the well. Based on the suitable dose range obtained in preliminary experiments, the concentration of RIP was set as 25, 50, 100, 200, 400, $800 \mathrm{mg} / \mathrm{L}, 6$ wells for each concentration. The continued culture was performed for $48 \mathrm{~h}$ at $37^{\circ} \mathrm{C}$ with $5 \% \mathrm{CO}_{2}$ and saturated humidity. At $4 \mathrm{~h}$ before the end of culture, $20 \mu \mathrm{L}$ of methylthiazolyldiphenyl-tetrazolium bromide (MTT) was added to each well. At the end of culture, the supernatant was discarded and $200 \mu \mathrm{L}$ of dimethyl sulphoxide was added to each well, followed by oscillation for $5 \mathrm{~min}$. The optical density (OD) of each well was measured by the microplate reader (wavelength $570 \mathrm{~nm}$ ). The higher OD value represented the higher cell activity.

\subsection{Determination of direct killing effect of RIP on HSV-2}

RIP with different concentration $(25,50,100,200,400,800 \mathrm{mg} / \mathrm{L})$ was mixed with the same amount of 100 TCID $_{50}$ HSV-2 fluid, followed by standing at $37^{\circ} \mathrm{C}$ for $4 \mathrm{~h}$. The incubation fluid was added to the monolayer of Vero cells, $200 \mu \mathrm{L}$ for each well, followed by standing at $37^{\circ} \mathrm{C}$ for $1.5 \mathrm{~h}$. The supernatant liquid was changed by $200 \mu \mathrm{L}$ of $2 \%$ DMEM, followed by continued culture for $72 \mathrm{~h}$. The cytopathic effect (CPE) was observed under inverted microscope, and the results were recorded as follows: 0\% CPE: -; 1-25\%: +; 25-50\%: ++; 50-75\%: +++; 75-100\%: ++++ . At the same time, the virus group and normal cell group were set, 6 wells for each group. The OD value of each well was measured by MTT method.

\subsection{Determination of inhibitory effect of RIP on HSV-2 replication}

$100 \mathrm{TCID}_{50} \mathrm{HSV}-2$ fluid was inoculated into monolayer of Vero cells, $100 \mu \mathrm{L}$ for each well, followed by adsorption at $37^{\circ} \mathrm{C}$ for $2 \mathrm{~h}$. The virus fluid was discarded, and the $2 \%$ DMEM containing RIP with different concentration $(25,50,100,200,400,800 \mathrm{mg} / \mathrm{L})$ was added, followed by continued culture for $72 \mathrm{~h}$. The CPE was observed under inverted microscope, and the results were recorded. At the same time, the virus group and normal cell group were set, 6 wells for each group. The OD value of each well was measured by MTT method. The antiviral effective rate of RIP was calculated as follows: effective rate $(\%)=$ (average $\mathrm{OD}_{\mathrm{RIP} \text { group }}$ - average $\left.\mathrm{OD}_{\text {virus group }}\right) /$ average $\mathrm{OD}_{\text {virus group }} \times 100 \%$.

\subsection{Determination of inhibitory effect of RIP on HSV-2 adsorption}

RIP with different concentration $(25,50,100,200,400,800 \mathrm{mg} / \mathrm{L})$ was mixed with the same amount of 100 TCID $_{50}$ HSV-2 virus, followed by direct inoculating into monolayer of Vero cells, $200 \mu \mathrm{L}$ of mixture for each well, followed by adsorption at $37^{\circ} \mathrm{C}$ of $2 \mathrm{~h}$. The supernatant was removed, and the $2 \%$ DMEM was added, $200 \mu \mathrm{L}$ for each well, followed by continued culture for $72 \mathrm{~h}$. The CPE was observed under inverted microscope, and the results were recorded. At the same time, the virus group and normal cell group were set, 6 wells for each group. The OD value of each well was measured by MTT method. The antiviral effective rate of RIP was calculated.

\subsection{Statistical analysis}

All statistical analysis was carried out using SPSS20.0 software (SPSS Inc., Chicago, IL, USA). The data were presented as mean $\pm \mathrm{SD}$, and were compared using y one-way ANOVA with SNK-q test. $\mathrm{P}<0.05$ was considered as statistically significant.

\section{Results}

\subsection{Virus virulence test result}

The test of Reed-Muench method showed that, the TCID $_{50}$ of the virus was $10^{-5}$. The virus concentration used in this study was $100 \mathrm{TCID}_{50}$.

\subsection{Toxicity of RIP on Vero cells}

Microscopy showed that, the morphology of Vero cells treated by RIP presented a tight and orderly arrangement, without shedding, fusion or round retraction, which was not significantly different from the morphology of normal cells. At the same time, MTT test showed that, there was no significant difference in cell proliferation between each concentration of RIP and normal cells $(\mathrm{P}>0.05)$. This indicated that, RIP in the concentration range of 25-800 mg/L had no toxic effect on Vero cells (Table 1).

Table 1. Toxicity of RIP on Vero cells.

\begin{tabular}{ccc}
\hline Group & Dose $(\mathrm{mg} / \mathrm{L})$ & OD $_{570 \mathrm{~nm}}$ \\
\hline Norma cells & - & $0.49 \pm 0.06$ \\
RIP & 25 & $0.50 \pm 0.04$ \\
& 50 & $0.51 \pm 0.07$ \\
100 & $0.53 \pm 0.07$ \\
200 & $0.51 \pm 0.08$ \\
400 & $0.52 \pm 0.06$ \\
& 800 & $0.53 \pm 0.08$ \\
\hline
\end{tabular}

RIP: Radix Isatidis polysaccharide; OD: optical density. 


\subsection{Direct killing effect of RIP on HSV-2}

The CPE of HSV-2 infection of Vero cells was characterized by swelling, rounding, intercellular fusion, abscission and fragmentation. The typical CPE caused HSV-2 infection appeared in RIP group with different concentrations. MTT showed that, the cell proliferation activity $\left(\mathrm{OD}_{570 \mathrm{~nm}}\right)$ of virus group was significantly lower than that in normal cell group $(\mathrm{P}<0.05)$. The $\mathrm{OD}_{570 \mathrm{~nm}}$ in each RIP group was also significantly lower than that in normal cell group $(\mathrm{P}<0.05)$, with no significant difference with the virus group $(\mathrm{P}>0.05)$. This indicated that, the RIP with different concentrations could not directly inactivate the HSV-2 (Table 2).

\subsection{Inhibitory effect of RIP on $\mathrm{HSV}-2$ replication}

Compared with the normal cell group, the virus group showed typical CPE features including swelling, rounding, intercellular fusion, abscission and fragmentation, and the cell proliferation activity $\left(\mathrm{OD}_{570 \mathrm{~nm}}\right)$ decreased significantly $(\mathrm{P}<0.05)$. Compared with virus group, the typical CPE features in RIP group with concentrations of 200, 400 and $800 \mathrm{mg} / \mathrm{L}$ were reduced, and the cell proliferation activity $\left(\mathrm{OD}_{570 \mathrm{~nm}}\right)$ was decreased significantly, respectively $(\mathrm{P}<0.05)$. The effective rate on inhibition of HSV-2 replication in $800 \mathrm{mg} / \mathrm{L}$ RIP group was $71.57 \%$, which was the highest (Table 3).

Table 2. Direct killing effect of RIP on HSV-2.

\begin{tabular}{cccc}
\hline Group & Dose $(\mathrm{mg} / \mathrm{L})$ & $\mathrm{OD}_{570 \mathrm{~nm}}$ & $\mathrm{CPE}$ \\
\hline Virus & - & $0.38 \pm 0.04^{*}$ & +++ \\
Norma cell & - & $0.70 \pm 0.07$ & - \\
RIP & 25 & $0.36 \pm 0.05^{\star}$ & +++ \\
& 50 & $0.37 \pm 0.06^{\star}$ & +++ \\
& 100 & $0.38 \pm 0.07^{\star}$ & +++ \\
200 & $0.40 \pm 0.06^{*}$ & +++ \\
& 400 & $0.39 \pm 0.07^{\star}$ & +++ \\
& 800 & $0.40 \pm 0.06^{*}$ & +++ \\
\hline
\end{tabular}

0\% CPE: -; 50-75\% CPE: +++; RIP: Radix Isatidis polysaccharide; HSV-2type: II herpes simplex virus; OD: optical density; CPE: cytopathic effect; ${ }^{\star} \mathrm{P}<0.05$ compared with normal cell group.

Table 3. Inhibitory effect of RIP on HSV-2 replication.

\begin{tabular}{ccccc}
\hline Group & Dose $(\mathrm{mg} / \mathrm{L})$ & $\mathrm{OD}_{570 \mathrm{~nm}}$ & $\mathrm{CPE}$ & $\begin{array}{c}\text { Effective } \\
\text { rate }(\%)\end{array}$ \\
\hline Virus & - & $0.31 \pm 0.03^{*}$ & +++ & \\
Norma cell & - & $0.55 \pm 0.09$ & - & 0.96 \\
RIP & 25 & $0.32 \pm 0.04^{*}$ & +++ & 1.92 \\
& 50 & $0.32 \pm 0.04^{*}$ & +++ & 7.35 \\
& 100 & $0.34 \pm 0.04^{*}$ & +++ & 39.3 \\
& 200 & $0.50 \pm 0.05^{\#}$ & ++ & 46.65 \\
& 400 & $0.51 \pm 0.04^{\#}$ & ++ & 71.57 \\
\hline
\end{tabular}

0\% CPE: -; 1-25\% CPE: +; 25-50\% CPE: ++; 50-75\% CPE: +++; RIP: Radix Isatidis polysaccharide; HSV-2type: II herpes simplex virus; OD: optical density; CPE: cytopathic effect; ${ }^{*} \mathrm{P}<0.05$ compared with normal cell group; ${ }^{*} \mathrm{P}<0.05$ compared with virus group.

\subsection{Inhibitory effect of RIP on HSV-2 adsorption}

Compared with the normal cell group, the virus group also showed typical CPE features, and the cell proliferation activity $\left(\mathrm{OD}_{570 \mathrm{~nm}}\right)$ decreased significantly $(\mathrm{P}<0.05)$. Compared with virus group, the typical CPE features in RIP group with concentrations of 400 and $800 \mathrm{mg} / \mathrm{L}$ were reduced, and the cell proliferation activity $\left(\mathrm{OD}_{570 \mathrm{~nm}}\right)$ was decreased significantly, respectively $(\mathrm{P}<0.05)$. The effective rate on inhibition of HSV-2 adsorption in $800 \mathrm{mg} / \mathrm{L}$ RIP group was $48.37 \%$, which was the highest (Table 4).

\section{Discussion}

HSV-2 is a common human infectious disease virus. It can cause herpes simplex, genital herpes, encephalitis, keratitis, visceral infection and so on. In addition, HSV-2 is associated with cervical cancer (Cao et al., 2014). At present, there are more than 50 kinds of medicine for resisting the herpes virus, but only a few drugs including acyclovir are recognized effective and applied in clinic for systemic infection. The targets of the vast majority of antiviral drug are DNA synthetases. The virus resistant to one drug often show cross resistance to other drugs (Tchesnokov et al., 2006). In recent years, in the process of seeking effective antiviral drugs, a variety of natural products are discovered, which have inhibitory effect on virus (Lin et al., 2014).

Many Chinese herbal medicines have the function of enhancing immunity and inhibiting and killing pathogenic microorganisms. These medicines have the characteristic of low toxic effect, low residue, safety and high efficiency. They have always been the focus of new drug research and development (Yang et al., 2008). As the antipyretic and detoxification drug, Radix Isatidis can be directly act with the immune organs, immune cells and the secreted antibodies, cytokines or the central nervous system. It can modulate the immune system, and stimulate the antibacterial, antiviral and antioxidant ability of body through improving the immune function (Kong et al., 2008; Fang et al., 2009). In TCM, Radix Isatidis is one of antiviral medicines. RIP is the main active component of Radix Isatidis, and has many biological activities such as immunoregulation (Zhao et al., 2008), anti-inflammation (Du et al., 2013) and liver protection (He et al., 2011). In recent years, the antiviral effect of RIP has obtained more and more attention. Chen et al.

Table 4. Inhibitory effect of RIP on HSV-2 adsorption.

\begin{tabular}{ccccc}
\hline Group & Dose $(\mathrm{mg} / \mathrm{L})$ & $\mathrm{OD}_{570 \mathrm{~nm}}$ & $\mathrm{CPE}$ & $\begin{array}{c}\text { Effective } \\
\text { rate }(\%)\end{array}$ \\
\hline Virus & - & $0.37 \pm 0.04^{\star}$ & +++ & \\
Norma cell & - & $0.56 \pm 0.07$ & - & \\
RIP & 25 & $0.37 \pm 0.05^{\star}$ & +++ & 0.82 \\
& 50 & $0.39 \pm 0.05^{*}$ & +++ & 5.43 \\
& 100 & $0.41 \pm 0.05^{*}$ & +++ & 12.50 \\
& 200 & $0.42 \pm 0.05^{*}$ & +++ & 13.86 \\
& 400 & $0.51 \pm 0.05^{\#}$ & ++ & 38.04 \\
& 800 & $0.55 \pm 0.07^{\#}$ & + & 48.37 \\
\hline
\end{tabular}

0\% CPE: -; 1-25\% CPE: +; 25-50\% CPE: ++; 50-75\% CPE: +++; RIP: Radix Isatidis polysaccharide; HSV-2type: II herpes simplex virus; OD: optical density; CPE: cytopathic effect; ${ }^{*} \mathrm{P}<0.05$ compared with normal cell group; ${ }^{*} \mathrm{P}<0.05$ compared with virus group. 
(2006) has isolated an antiviral polysaccharide with relatively uniform molecular weight distribution from Radix Isatidis. They find that, the polysaccharide can not only act directly on the virus, but also promote the generation of anti-influenza virus IgG antibodies. Therefore, the polysaccharide can be used as adjuvant for antiviral vaccines. In addition, Zhao et al. (2008) have used RIP solution to intraperitoneally inject the modeled mice infected with influenza virus. The mouse survival time and lung index are observed, and the changes of serum antiviral IgG level and spleen cell IFN- $\gamma$ level are determined. Results find that, RIP can promote nonspecific immunity and enhance humoral immune function. In addition, it can participate in the regulation of cellular immune function, thereby enhancing the ability of mice to resist influenza virus infection.

This study has investigated the antiviral activities of RIP against HSV-2 in vitro. Results indicated that, RIP in the concentration range of $25-800 \mathrm{mg} / \mathrm{L}$ had no toxic effect on Vero cells. This indicates that, RIP is the safe drug to the cells. MTT assay showed that, the RIP with different concentrations could not directly inactivate the HSV-2, but could inhibit the replication and adsorption of HSV-2. This indicates that, PSP has significant anti-HSV-2 effects in vitro. This effect mainly occurs in inhibiting the virus duplication and adsorption, which is obviously different from acyclovir, so it is difficult to produce drug resistance. RIP is a natural compound, and has the characteristics of non-toxicity and high efficiency. Moreover, it has both antiviral and immunomodulatory effects. This is also an advantage that synthetic drugs do not have. Therefore, RIP has the prospect of developing new antiviral drugs.

\section{Conclusions}

RIP has the antiviral effect against HSV-2 in vitro. This effect mainly occurs in inhibiting the virus duplication and adsorption. However, the exact mechanism on RIP affecting the replication cycle of viruses in host cells remains to be further studied.

\section{References}

Bacon, T. H., Levin, M. J., Leary, J. J., Sarisky, R. T., \& Sutton, D. (2003). Herpes simplex virus resistance to acyclovir and penciclovir after two decades of antiviral therapy. Clinical Microbiology Reviews, 16(1), 114-128. PMid:12525428. http://dx.doi.org/10.1128/CMR.16.1.114128.2003.

Cao, S., Gan, Y., Dong, X., \& Lu, Z. (2014). Herpes simplex virus type 2 and the risk of cervical cancer: a meta-analysis of observational studies. Archives of Gynecology and Obstetrics, 290(6), 1059-1066. PMid:25030659. http://dx.doi.org/10.1007/s00404-014-3365-7.

Chen, Z. W., Wu, L. W., Liu, S. T., Cai, C. P., Rao, P. F., \& Ke, L. J. (2006). Mechanism study of anti-influenza effects of Radix Isatidis water extract by red blood cells capillary electrophoresis. Zhongguo Zhongyao Zazhi, 31(20), 1715-1719. PMid:17225545.
Du, Z., Liu, H., Zhang, Z., \& Li, P. (2013). Antioxidant and antiinflammatory activities of Radix Isatidis polysaccharide in murine alveolar macrophages. International Journal of Biological Macromolecules, 58, 329-335. PMid:23603085. http://dx.doi. org/10.1016/j.ijbiomac.2013.04.037.

Fang, J., Wan, J., Tang, J., Wang, W., \& Liu, Y. (2009). Radix isatidis and infectious diseases caused by viruses. Zhongguo Zhongyao Zazhi, 34(24), 3169-3172. PMid:20352991.

Gustafsson, R. K., Engdahl, E. E., \& Fogdell-Hahn, A. (2012). Development and validation of a Q-PCR based TCID50 method for human herpesvirus 6. Virology Journal, 9(1), 311. PMid:23249654. http:// dx.doi.org/10.1186/1743-422X-9-311.

He, L., Li, X., Wang, H., Chen, J., Sun, D., \& Wang, M. (2011). Structures and bioactivity of polysaccharides from isatidis radix. Zhongguo Zhongyao Zazhi, 36(16), 2179-2182. PMid:22097324.

Ke, L., Wen, T., Bradshaw, J. P., Zhou, J., \& Rao, P. (2012). Antiviral decoction of Isatidis Radix (băn lán gēn) inhibited influenza virus adsorption on MDCK cells by cytoprotective activity. Journal of Traditional and Complementary Medicine, 2(1), 47-51. PMid:24716114. http://dx.doi.org/10.1016/S2225-4110(16)30070-0.

Kong, W., Zhao, Y., Shan, L., Xiao, X., \& Guo, W. (2008). Thermochemical studies on the quantity-antibacterial effect relationship of four organic acids from Radix Isatidis on Escherichia coli growth. Biological \& Pharmaceutical Bulletin, 31(7), 1301-1305. PMid:18591764. http:// dx.doi.org/10.1248/bpb.31.1301.

Lin, L. T., Hsu, W. C., \& Lin, C. C. (2014). Antiviral natural products and herbal medicines. Journal of Traditional and Complementary Medicine, 4(1), 24-35. PMid:24872930. http://dx.doi.org/10.4103/22254110.124335 .

Schiffer, J. T., \& Corey, L. (2013). Rapid host immune response and viral dynamics in herpes simplex virus- 2 infection. Nature Medicine, 19(3), 280-290. PMid:23467247. http://dx.doi.org/10.1038/nm.3103.

Tchesnokov, E. P., Gilbert, C., Boivin, G., \& Götte, M. (2006). Role of helix $\mathrm{P}$ of the human cytomegalovirus DNA polymerase in resistance and hypersusceptibility to the antiviral drug foscarnet. Journal of Virology, 80(3), 1440-1450. PMid:16415021. http://dx.doi. org/10.1128/JVI.80.3.1440-1450.2006.

Yang, L., Hu, Y., Xue, J., Wang, F., Wang, D., Kong, X., Li, P., \& Xu, W. (2008). Compound Chinese herbal medicinal ingredients can enhance immune response and efficacy of RHD vaccine in rabbit. Vaccine, 26(35), 4451-4455. PMid:18602959. http://dx.doi.org/10.1016/j. vaccine.2008.06.075.

Yanhua, W., Fuhua, W., Zhaohan, G., Mingxing, P., Yanan, Z., Ling, P. Z., Minhua, D., Caiying, Z., \& Zian, L. (2014). Optimization of extraction process for polysaccharide in Salvia Miltiorrhiza Bunge using response surface methodology. The Open Biomedical Engineering Journal, 8, 153-159. http://dx.doi.org/10.2174/187412 0701408010153. PMid:26312073.

Zhao, Y. L., Wang, J. B., Shan, L. M., Jin, C., Ma, L., \& Xiao, X. H. (2008). Effect of Radix isatidis polysaccharides on immunological function and expression of immune related cytokines in mice. Chinese Journal of Integrative Medicine, 14(3), 207-211. PMid:18853118. http:// dx.doi.org/10.1007/s11655-008-0207-2. 